\title{
STUDENTS' ATTITUDE TOWARDS DOING WHILE-READING COMPREHENSION EXERCISES USING MICROSOFT FORMS
}

\section{Tu Thi Thanh Tran}

\section{Article History}

Received: July 26, 2020

Accepted: August 17, 2020

Published: September 30, 2020

\section{Keywords}

Reading comprehension skill, while-reading activities, Microsoft Forms, students' attitude

\author{
Lecturer of English, Ba Ria - Vung Tau College of Education, Vietnam \\ Email: tranthanhtusp@gmail.com
}

\section{INTRODUCTION}

2020 is the year in which the world has been going through a global pandemic due to a virus called Corona. The teaching and learning of teachers and students respectively has undergone considerable changes. Both teachers and students are unable to embrace traditional teaching with face-to-face interaction, necessitating the application of online learning model. My College of Education is no exception, making efforts to adopt suitable online teaching platforms for each discipline. In the second semester, one of the modules I was assigned to teach was Reading 1 for freshmen. Within 35 periods, this Reading module has 2 major contents: 7 comprehension readings in Burgmeier's Inside Reading ( $2^{\text {nd }}$ ed) (2012) and tests in Preliminary English Test 2 (2007), Preliminary English Test 3 (2007) and Preliminary English Test 1 (2019) by Oxford University Press. As a lecturer of English, I chose Microsoft Forms (MS Forms) as a means of delivering while-reading activities for the reading texts. Since little has been known about the applicability of MS Forms in English reading comprehension classes, the present action research is carried out to give more insights into the benefits as well as some barriers of using MS Forms in reading comprehension classes.

It is the aim of this paper to give examples of some while-reading activities using MS Forms and present students' attitude towards doing such while-reading comprehension exercises using MS Forms.

\section{LITERATURE REVIEW}

Reading, which is a complex process, has been defined in numerous ways by various educational researchers and practitioners.

Back in the year 1982, reading, according to the Nuttall (1982, p.2), was comprised of three dimensions (1) decoding, deciphering, identifying, (2) articulating, speaking, pronouncing, and (3) understanding, interpreting, meaning, sense. The author did a great job in naming three different essential elements of reading. In concert with this, Fazeli (2010, p.374) goes a bit further in the assertions that "reading is not a mere process of decoding" and that in a general sense, "reading happens when people look at a text and assign meaning to written symbols in that text" (p. 376). In roughly the same line of thought, albeit in a much more succinct and sophisticated way, Zimmerman and Hutchins (2003) did clarify the term "reading" by its core elements, external and internal ones, decoding words, understanding and comprehending (assigning meaning).

There are two elements of reading. The first part is the external element of reading. This is decoding words. Many students can decode words, but students do not always understand what decoded words and sentences mean. To an outsider, students look as though they are reading when they are decoding words. They are reading the words in front of them; however, there is more to reading than just decoding. There is also the internal element of reading. The internal element of reading is the actual understanding of the text that allows students to comprehend the content; it is when readers engage with the text and truly think about what they are reading. When readers are engaged, they are 
actively reading and monitoring the conversation in their head (Zimmerman and Hutchins, 2003, cited in Gibson, 2009, p.14).

The above definition seems to echo what Ur (2012, p.133) has put it "In the context of language learning, reading means 'reading and understanding'. A student who says, 'I can read the words but I don't know what they mean' is not, therefore, reading, in this sense, but merely decoding: translating the written symbols into their corresponding sounds."

The teaching of reading is quite complicated since according to Grabe (2004):

Evidently, many different things can be going on when a reader reads: the process is likely to be dynamic, variable and different for the same reader on the same text at a different time or with a different purpose in reading. It is even more likely, then, that the process will be different for different readers on different texts at different times and with different purposes. (Grabe, 2004, p.3).

Despite many variables that can exert certain influences on the readers in the three-phase approach suggested in Sacricoban (2002), Xiaoguang Zhao \& Lei Zhu (2012) before reading (pre-reading), while reading (while-reading) and after reading (post-reading), students' comprehension of some reading texts; anyway, can be achieved and assessed through the use of while-reading activities, typically, according to Harmer (1998), scanning for particular bits of information students are searching for, skimming to get a general idea of what the text is about, reading for detailed comprehension - students concentrating on the minutiae of what they are reading.

Ur (2012) also points out the use of reading texts for intensive language learning, thereby suggesting four relevant primary goals: comprehension of content, language learning, discourse analysis and enrichment through further tasks based on different aspects of learning.

As far as MS Forms is concerned, it can be used to create quizzes and invite others to respond to it using almost any web browser or mobile device, see real-time results as they're submitted, use built-in analytics to evaluate responses, and export results to Excel for additional analysis or grading (https://support.office.com/en-us/article/Introduction-toMicrosoft-Forms-bb1dd261-260f-49aa-9af0-d3dddcea6d69). The software does allow the instructor to assign a score for each question, respond to options in the choice question, set the exam time, and give feedback. Also, the test is automatically graded and the results can be returned either in MS Teams or exported to Excel.

The types of questions available in Forms Pro are Choice (Single-answer question, Multiple-answer question), Text (Short-answer question, Long-answer question), Rating, Date, Ranking, Net Promoter Score, and Likert (https://docs.microsoft.com/en-us/forms-pro/plan-survey), out of which the first two task types are popular activities to do with while-reading stage activities.

This is not the aim of this article; however, to go into depth the efficiency of certain reading strategies but to focus on students' attitude towards the comprehension of text content through a wealth of while-reading activities carried out by the researcher via a Microsoft software called MS Forms since MS Forms and its applicability in while-reading activities are yet studied and discussed. The activities can be about Vocabulary. It can; alternatively, be about understanding details and understanding the main idea of a text, as in Alderson (2000) or reading "the lines" and reading "between the lines", with the former referring to the literal meaning of the text and the latter to the inferred meaning as in Gray (1960, cited in Alderson, 2000).

Within the scope of this article, I present the results I collected regarding students' attitudes towards doing whilereading comprehension exercises based on the content in Inside Reading 1 ( $2^{\text {nd }}$ ed) after students' exposure to doing while-reading comprehension exercises using MS Forms.

\section{RESEARCH METHODS AND RESULTS}

\subsection{Research subjects and methods}

Participants in the research were 31 first-year English majors from the Department of Foreign Languages, four of whom were male. They were the students participating in the 35-period Reading 1 course and in the doing of while-reading activities based on the course reading passages using MS Forms over a course of over 4 months commencing at the beginning of March, which was longer than the expected 15 successive weeks.

In this action research model, which basically involved the four repeated steps suggested by Lewin (1946, cited in Coghlan and Jacobs (2005) as Planning, Acting, Observing and Reflecting, both qualitative and quantitative methods were used in data collection although the former formed a bit more significant part in this study, all to have a better picture about students' attitude towards doing while-reading activities using MS Forms. During the implementation of the study, methods such as observation, interviews, and questionnaire (in both Vietnamese and English) were used in unison. After all the activities had been carried out, the researcher delivered a questionnaire to 
see how students felt about doing while-reading exercises using MS Forms. After that, the teacher-researcher conducted in-depth interviews and posed some questions to elaborate more on some ideas commented by the student participants.

\subsection{Action}

Apart from the traditional black-and-white Multiple Choice or Gap-fill, to name but two while-reading activities, the researcher designed some more while-reading activities for the class reading content in MS Forms and delivered assignments to students via MS Teams or links.

Below are some examples that the researcher designed for some of the reading texts in the reading course.

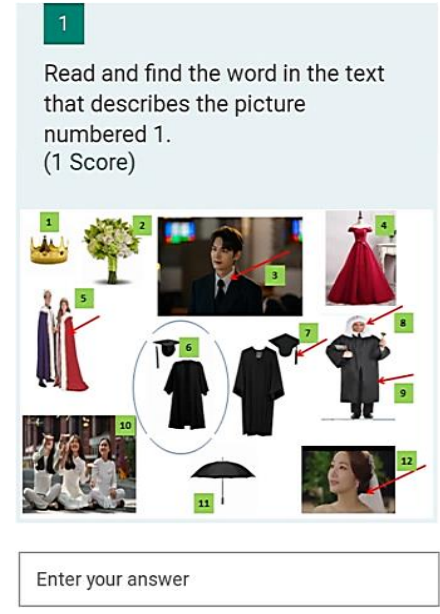

The correct answer: crown, a crown

Figure 1

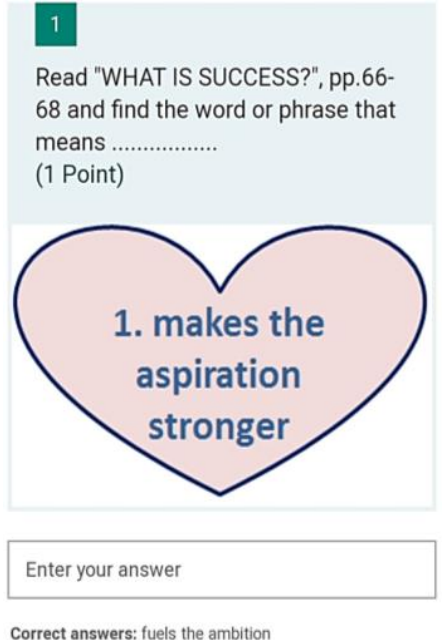

Figure 2

With a view to drawing students' attention to some key vocabularies as well as assisting students in being better prepared for the reading comprehension tasks, vocabulary activities like above were conducted. With this whilereading activity, from the teacher-researcher's perspective, it could help students with their skimming and scanning. They needed to use their own schemata and went to the reading parts where they thought the word(s) or phrase(s) they were looking for would be, locate and find the corresponding word(s)/phrase(s) with the given picture (Figure 1) or word/phrase given (Figure 2) in the fastest way possible. For example, in order to find the word for number 8 (Figure 1), a certain quick idea would flash into students' mind, thanks to their understanding of the world around them, encouraging them to "jump" to In Civil Courts of Law instead of In Universities, Among Royalty, Wedding Symbols or Uniforms in search of the correct answer.

Another example of while-reading activities using MS Forms can be as follows:

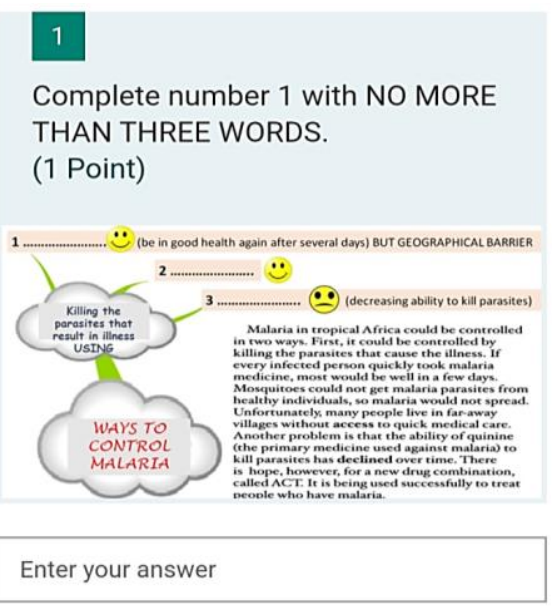

Correct answers: medicine

Figure 3

\section{4}

Complete number 4 with NO MORE THAN THREE WORDS. (1 Point)

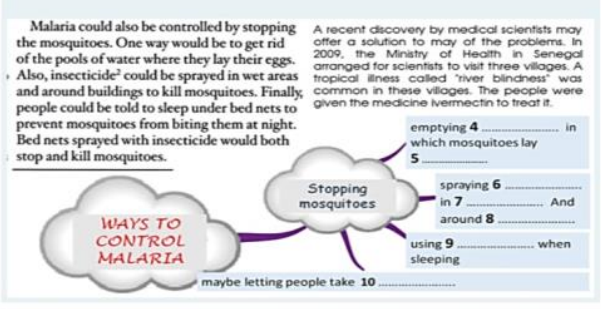

Enter your answer

Correct answers: pools of water

Figure 4 
Occasionally, if there was space on the screen, I created exercises like Figure 3 and Figure 4 (with both questions and relevant reading text). With this arrangement, the teacher-researcher believes that students could do reading comprehension exercises right in Forms without opening their books to read. This contributes to a change in students' learning practice and helps create a new "experience", albeit minimum for students.

Besides, while-reading activities can be in the form of a grid like this:

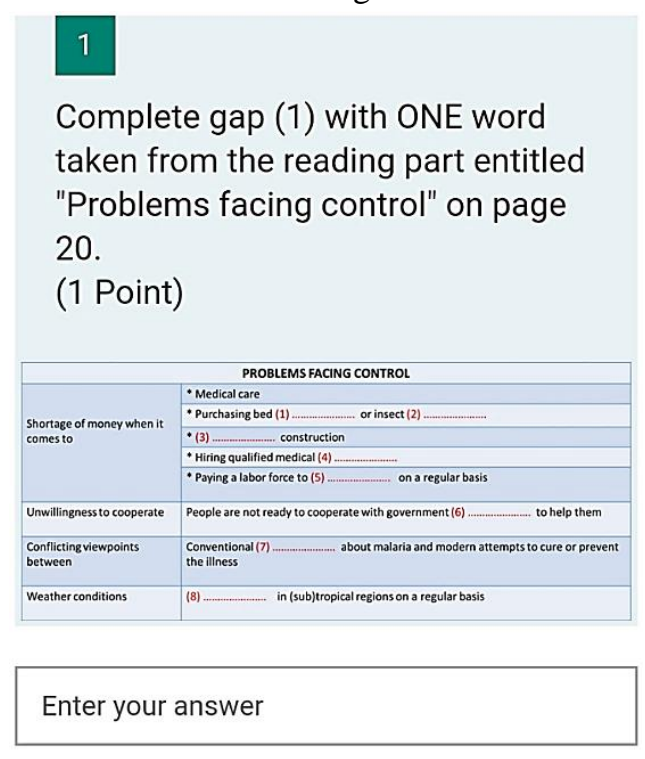

Correct answers: nets

Some other popular task types as far as while-reading is concerned are True/ False/ Not Given, Answering the questions, Filling in the gaps, to name but a few.

\subsection{Data Analysis and Discussion}

Below are some data related to how the study participants perceived the act of doing comprehension exercises in MS Forms particularly about the positives and negatives of using MS Forms in while-reading activities. The items are based on some of the built-in features of MS Forms.

Table 1. Students' perception on the use of MS Forms in while-reading activities

\begin{tabular}{|c|c|c|c|c|c|}
\hline & $\begin{array}{c}\text { Totally } \\
\text { disagree }\end{array}$ & Disagree & Neutral & Agree & $\begin{array}{c}\text { Totally } \\
\text { agree }\end{array}$ \\
\hline $\begin{array}{l}\text { The appearance of the colorful pictures right } \\
\text { in front of me while reading helps me focus } \\
\text { on completing the reading task. }\end{array}$ & $\begin{array}{c}1 \\
(3 \%)\end{array}$ & $\begin{array}{c}1 \\
(3 \%)\end{array}$ & $\begin{array}{c}0 \\
(0 \%)\end{array}$ & $\begin{array}{c}24 \\
(78 \%)\end{array}$ & $\begin{array}{c}5 \\
(16 \%)\end{array}$ \\
\hline $\begin{array}{l}\text { That I always see the question(s) right in front } \\
\text { of me motivates me to read and discover the } \\
\text { answer to the question and the meaning of the } \\
\text { passage as well. }\end{array}$ & $\begin{array}{c}1 \\
(3 \%)\end{array}$ & $\begin{array}{c}1 \\
(3 \%)\end{array}$ & $\begin{array}{c}1 \\
(3 \%)\end{array}$ & $\begin{array}{c}16 \\
(52 \%)\end{array}$ & $\begin{array}{c}12 \\
(39 \%)\end{array}$ \\
\hline $\begin{array}{l}\text { The time pressure and competitiveness } \\
\text { amongst peers make me try to do and finish } \\
\text { the task. }\end{array}$ & $\begin{array}{c}0 \\
(0 \%)\end{array}$ & $\begin{array}{c}0 \\
(0 \%)\end{array}$ & $\begin{array}{c}7 \\
(23 \%)\end{array}$ & $\begin{array}{c}9 \\
(29 \%)\end{array}$ & $\begin{array}{c}15 \\
(48 \%)\end{array}$ \\
\hline $\begin{array}{l}\text { A sense of achievement that I have when } \\
\text { completing the task before or on time } \\
\text { facilitates me to do the task to the best of my } \\
\text { ability. }\end{array}$ & $\begin{array}{c}0 \\
(0 \%)\end{array}$ & $\begin{array}{c}0 \\
(0 \%)\end{array}$ & $\begin{array}{c}5 \\
(16 \%)\end{array}$ & $\begin{array}{c}10 \\
(32 \%)\end{array}$ & $\begin{array}{c}16 \\
(52 \%)\end{array}$ \\
\hline
\end{tabular}

It is revealed from Table 1 that positive reactions from the students were recorded when it comes to doing whilereading comprehension exercises via MS Forms, specifically, it helped boost students' focus, at least in their perception, thanks to vivid images (94\%), motivation to read and discover answers to questions as well as the meaning of the reading from the exercise being right in front of their eyes on their hi-tech equipment (91\%), time 
pressure and competition with classmates (77\%), the feeling of accomplishment when completing the exercise on time $(84 \%)$.

As for the vocabulary activities, some students wrote that "I found doing vocabulary exercises in MS Forms helps us work out the words in a vivid way and learn more new words in an interesting way." Although the teacherresearcher did remind students to read and find the words, a few of them still looked up the word in the dictionary, resulting in their writing of the words that could not be found elsewhere in the reading text, such as cloak (instead of robe) for picture numbered 9 in Figure 5. This did not fall short of the teacher-researcher's notice as Çetinavc1 (2014) put it that "Context provides various clues to make the process of guessing the vocabulary of readers easier." With this problem, the teacher did encourage the whole class one more time to follow the teacher's instructions for the improvement of their guessing skill in specific (guessing words based on the context in which they appear) and their reading skill in general. What is worth noting here is the comment made by one student as one of the drawbacks of using MS Forms in while-reading activities, which was translated by the teacher-researcher into English as "The vividly colored pictures sometimes captured so much of my attention that I kept looking at them. For example, when I saw my idol in one of the pictures, Lee Min Ho, I just couldn't help admiring his beauty. He is such an eyeful. Hihi'”. This necessitated the teacher's tactics in choosing pictures, so as not to be too trendy, too colorful or eye-catching and also not to be too "obsolete".

Although a vast majority of the students expressed their agreement to the motivation to read and discover the answer to the question and the meaning of the whole passage from constantly seeing the question(s) right in front of them, attention should also be paid to the fact that due to unstable internet connection now and then especially at some peak time, the exercise took long to appear in its expected way in students' device and the students got a bit angry facing a black screen." "Doing homework on MS Forms is very convenient, easy to learn and do. But, it is difficult because when the network is down, it is impossible to use this operation, so it is very annoying. "Confronting with this problem, the teacher should try not to cling to this single mode of delivering exercises - MS Forms but should be more flexible finding other ways, using other platforms, if possible, to help the exercise be within reach of the students so that they can still keep doing it, all for the sake of students' language learning and development. Another disadvantage that some students encountered was "looking so long at the exercise, trying to complete it makes my eyes tired". This drawback seemed to get a bit more serious when the screen was filled with words. As this is one of the anticipated adverse effect of using technology on the physical health of the students especially their eyesight, teachers should try the best to give students some break time between periods of the lesson so that they could relax and refresh their eyes.

Time pressure was both motivating but at the same time challenging for learners of different reading skill levels. A telling example of students' motivation can be found in one of the students' comments "I think doing the reading exercises using MS forms is very interesting and very good. When you assign exercises, I'm sometimes lazy. But doing this using MS Forms, you have a deadline and time to submit it, so I got myself to do it." or another can be "I find it very interesting to do reading exercises in MS Forms. It urges me to do and complete because the time limit expires." On the flip side, time pressure made it difficult for other learners. According to the teacher's observation, it was hard for some students with relatively low English proficiency compared with their friend counterparts. They felt a little nervous when they thought they would not finish the exercise ahead of time or just in time. This should be addressed to by the teacher and the onus, to the best of the teacher-researcher, is on the teachers themselves to encourage those students who are lagging behind to try to work under pressure so as to know where they are and make efforts accordingly. Also, it is advisable for teachers not to take students' grades into too serious consideration in order to prevent them from unexpected cheating and to use the Insights tool in MS Teams (if possible) in a "silent" way to see the progress of each individual so that teachers can offer timely assistance, support and guidance. This is all to facilitate students to make more endeavors to boost their reading skills in the belief that they are not alone in their learning journey and that their teachers are always with them or just behind them, following each of their steps taken forward, hoping that they will improve themselves. When asked why students felt they had a sense of achievement completing the task before or on time much as teachers in conventional classes could still set the time allotted, students explained that the technically recorded time tended to be "more exact" and devoid of the influence of human interference. As a result, they felt the stronger motivation to do the exercise to the best of their ability.

Apart from those upsides above, up to 20 students wrote as part of their answers to the question "What are the advantages of doing reading exercises in MS Forms" as roughly follows: "new interesting way", "new way of 
learning, I like it", "new way of doing reading exercises, ^ $0^{\wedge}$ ”, "brand-new experience”, "a new, helpful and fun way of learning reading and doing exercises", "I can learn a lot about reading and I can learn a lot about using technology in teaching", "I like it even more than traditionally doing reading exercises". This helps show the applicability of MS Forms into reading comprehension classes.

Just only one student expressed the difficulty in using the app. Although there was only one considering using MS Forms difficult, teachers should take this into account to make sure every single student knows how to use the new app to get the assigned exercise from the teacher and do it.

One more problem that students had was to do with the scoring of their exercise, which the teacher is to be responsible for. Students sometimes felt displeased with the mismatch between their answers, which they believe were acceptable and those from the software (which was in fact keyed in by the teacher). Dealing with this, the teacher did confirm whether their different answers were right or wrong when correcting the exercise with the whole class. This; however, sometimes was not enough to satisfy the students for how they had already been graded previously. Realizing this, the teacher did make better efforts in thinking of all the possible correct answers to avoid such a repeated error and dissatisfaction amongst students.

\section{DISCUSSION AND CONCLUSION}

From the above research and analysis, it can be concluded that students' doing while-reading exercises via MS Forms is potentially more often than not a positive experience if the network quality is stable enough. In addition, reading comprehension exercises using MS Forms with the advantages of the software as in the brand-new experience it offers, (2) the colorful and vivid images on the device (if yes), (3) the motivation to read and unveil the answers to the reading questions under time pressure and competitiveness with peers as well as (4) a sense of accomplishment completing assignments before or on time makes reading comprehension classes generally effective. This study is hoped to be a valuable reference resource for those who are still concerned with the feasibility of using MS Forms in English reading comprehension classes and suggest the introduction of MS Forms in conventional reading comprehension classes when the Internet connection is available and stable.

\section{REFERENCES}

Alderson, J. C. (2002). Assessing reading. Cambridge University Press.

Burgmeier, A. (2012). Inside Reading - The Academic World List in Context ( $2^{\text {nd }}$ ed). Oxford University Press.

Cetinavc1, B. M. (2014). Contextual factors in guessing word meaning from context in a foreign language. Procedia - Social and Behavioral Sciences, 116, 2670-2674.

Coghlan, D. \& Jacobs, C. (2005). Kurt Lewin on Reeducation: Foundations for Action Research. The Journal of Applied Behavioral Science, 41(4), 444-457.

Fazeli, S. H. (April 2010). Some gaps in the current studies of reading in second/ foreign language learning. Language in India, 10(4), 373-386.

Gibson, K. D. (2009). Teachers' perceptions of strategy based reading instruction for reading Comprehension. M.A. Thesis. Dominican University of California.

Grabe, W. (2004). 3. Research on teaching reading. Annual Review of Applied Linguistics, 24, 44-69.

Harmer, J. (1998). How to teach English. Addison Wesley Longman Limited.

https://docs.microsoft.com/en-us/forms-pro/plan-survey (2020).

https://docs.microsoft.com/vi-vn/ (2020).

https://support.office.com/en-us/article/Introduction-to-Microsoft-Forms-bb1dd261-260f-49aa-9af0-d3dddcea6d69 (2020).

Nuttall, C. (1982). Teaching Reading Skills in a Foreign Language. Oxford: Heinemann Publishers.

Saricoban, A. (2002). Reading Strategies of Successful Readers through the Three Phase Approach. The Reading Matrix, 2(3), 149-165.

University of Cambridge Esol Examinations (2007a). PET 2. Cambridge University Press.

University of Cambridge Esol Examinations (2007b). PET 3. Cambridge University Press.

University of Cambridge Esol Examinations (2019). PET 1. Cambridge University Press.

Ur, P. (2012). A Course in English Language Teaching. Cambridge University Press.

Zhao, X. \& Zhu, L. (2012). Schema Theory and College English Reading Teaching. Canadian Center of Science and Education, 5(11), 111-117. 